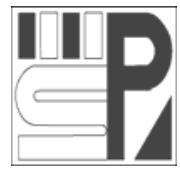

Science Press

\title{
Molecular phylogeny of tribe Atraphaxideae (Poly- gonaceae) evidenced from five cpDNA genes
}

\author{
YanXia SUN ${ }^{1}$, MingLi ZHANG ${ }^{1,2 *}$ \\ ${ }^{1}$ Key Laboratory of Biogeography and Bioresource in Arid Land, Xinjiang Institute of Ecology and Geography, Chinese Academy \\ of Sciences, Urumqi 830011, China; \\ ${ }^{2}$ Institute of Botany, Chinese Academy of Sciences, Beijing 100093, China
}

\begin{abstract}
Traditionally, Atraphaxis, Calligonum, Pteropyrum and Parapteropyrum are included in the tribe Atraphxideae. Recently, sequence data has revealed that this tribe is not monophyletic. The structure of the tribe was examined by adding more taxa and sequences to clarify the congruence between morphology and molecular phylogeny, the systematic placements of four genera in Polygonaceae, as well as the infra-generic relationships of Atraphaxis and Calligonum within Atraphaxideae. Five chloroplast genes, atpB-rbcL, $p s b A-t r n \mathrm{H}, \operatorname{trn} \mathrm{L}-\operatorname{trnF}$, psbK-psbl, and rbcL of Atraphaxis, Calligonum, Pteropyrum, and Parapteropyrum were sequenced. The non-monophyly of Atraphaxideae was confirmed. Atraphaxis and Calligonum, respectively, formed a monophyletic group that was well supported. Calligonum is closely related to Pteropyrum; Atraphaxis is sister to Polygonum s. str.; and Parapteropyrum is allied with Fagopyrum. Although the morphology suggested the four genera should form a tribe, the molecular data indicated Atraphaxideae was not one monophyletic group. The clades identified within Atraphaxis corresponded well with the current sectional classification based on morphological features. As for Calligonum, Medusa was identified as a non-monophyletic section.
\end{abstract}

Keywords: tribe Atraphaxideae; Atraphaxis; Calligonum; chloroplast genes; monophyly

Polygonaceae, in general, has two recognized subfamilies, Polygonoideae and Eriogonoideae (Jaretzky, 1925; Haraldson, 1978; Brandbyge, 1993; Heywood et al., 2007; Sanchez et al., 2011). Subfamily Polygonoideae has five tribes (Haraldson, 1978; Brandbyge, 1993; Sanchez and Kron, 2008), however, the tribal classification within this subfamily is under dispute. Tribe Atraphaxideae was proposed by Dammer (1893) to include the genera Atraphaxis, Calligonum, and Pteropyrum. Afterward, these three genera were treated as subtribe Atraphaxidinae (Jaretzky, 1925; Hong, 1995) or subfamily Calligonoideae (Hong, 1995); Haraldson (1978) and Brandbyge (1993) placed them in the tribe Polygoneae. Chinese researchers established the new Atraphaxideae genus (Parapteropyrum) from Tibet, China. At present, the tribe Atraphaxideae, according to the most widely accepted taxonomy, consists of Atraphaxis, Calligonum, Ptero- pyrum, and Parapteropyrum (Li et al., 1998; Takhtajan, 2009). These four genera are all shrubs, usually have five petals and a 3-coporate aperture. Most species of the tribe occur over an area including Central and Western Asia, westward to North Africa and Southeast Europe, and eastward to East Asia (Bao and Li, 1993; Li et al., 2003).

Bao and Li (1993) proposed a tribal classification system and postulated an evolutionary framework for Atraphaxideae. Based on the evolution of morphological characters as well as pollen and embryo, Atraphaxis was thought to be the most primitive genus. Jaretzky (1925) and Haraldson (1978) hypothe sized that Atraphaxis and Pteropyrum are related, but Hong (1995) presented evidences from the pollen of the four genera to show that Parapteropyrum is very similar to

Received 2011-09-15; accepted 2012-01-28

*Corresponding author: MingLi ZHANG (E-mail: zhangml@ibcas.ac.cn) 
Pteropyrum and Atraphaxis is different from the other three genera. After comparing thirty morphological characters in Atraphaxis, Calligonum and Pteropyrum, Tavakkoli et al. (2008) suggested that Calligonum and Pteropyrum are closely related.

The karyotype of the tribe provides useful taxonomic data. Jaretzky (1928) considered the basic chromosome number to be $\mathrm{n}=11$ in the Polygonaceae, with other values being derived from it. Recently, Tian et al. (2009) reported the chromosome karyotypes of two Atraphaxis species and Parapteropyrum. Parapteropyrum was found to be tetraploid $(2 x=48)$. Therefore, a notable difference among three of the genera within the tribe (Pteropyrum was not examined) was revealed by basic chromosome numbers, $\mathrm{n}=9$ for $\mathrm{Cal}$ ligonum, $\mathrm{n}=11$ for Atraphaxis, and, as Tian et al. (2009) suggested, $\mathrm{n}=12$ for Parapteropyrum. Calligonum also had polyploidy, including tetraploids and triploids (Mao et al., 1983). Most Atraphaxis species are diploid. Thus, the aneuploid evolution and polyploidy of the three genera studied provide a complicated background for the systematic and evolutionary history of Atraphaxideae, in combination with molecular phylogeny (Tian et al., 2009).

According to recent molecular phylogenies, Atraphaxis is related to the genera of the currently recognized tribe Polygoneae (Lamb-Frye and Kron, 2003; Sanchez and Kron, 2008; Sanchez and Kron, 2009; Sanchez et al., 2009; Tavakkoli et al., 2010). Calligonum and Pteropyrum form a clade, along with Pteroxygonum, but are distant from Atraphaxis (Sanchez et al., 2009, Tavakkoli et al., 2010). Meanwhile, Sanchez et al. (2009) using cpDNA and ITS sequence data showed that Atraphaxideae was not monophyletic, however, Parapteropyrum was absent from their chloroplast data. Tavakkoli et al. (2010) again demonstrated the polyphyly of Atraphaxideae using ITS and trnL-trnF sequence data by including four Atraphaxideae genera and focusing on several Calligonum and Pteropyrum species in Iran.

The previous molecular phylogenies, mainly focusing on higher taxonomic levels, have omitted Parapteropyrum, and have lacked adequate Atraphaxis samples. Considering the disagreement over relationships in Atraphaxideae, we attempted to explore the phy- logeny of Atraphaxideae by sampling more taxa and sequences, particularly to (1) further test the monophyly of Atraphaxideae; (2) investigate the diversification of the four Atraphaxideae genera; and (3) present a preliminary molecular phylogeny of Atraphaxis and Calligonum in China.

\section{Materials and methods}

\subsection{Taxon sampling}

We sampled eight species from Atraphaxis, nine from Calligonum, and one from Parapteropyrum and Pteropyrum, respectively (Table 1). All of them, except Pteropyrum (obtained from the LE herbarium), were sampled in China. The leaf materials were dried with silica gel from the botanical garden or field.

\subsection{DNA sequencing and alignment}

Total genomic DNA was extracted using the CTAB method (Doyle and Doyle, 1987). The polymerase chain reaction (PCR) was used for double stranded DNA amplification. Each $25 \mu \mathrm{L}$ reaction contained $0.25 \mu \mathrm{L}$ of Ex Taq $(2.5 \mathrm{u} / \mu \mathrm{L}), 2.5 \mu \mathrm{L}$ of $10 \times$ Ex Taq buffer $\left(\mathrm{Mg}^{2+}\right.$ concentration of $\left.25 \mathrm{mM}\right), 2.0 \mu \mathrm{L}$ of dNTP mix (at $2.5 \mathrm{mM}$ concentration for each dNTP), $1 \mu \mathrm{L}$ of each, forward and reverse primers at 5 $\mu \mathrm{mol} / \mu \mathrm{L}$. The following primers were used: trnL-trnF (Taberlet et al., 1991), atpB-rbcL (Janssens et al., 2006), psbAF (Sang et al., 1997) and trnHR (Tate and Simpson, 2003) for the psbA-trnH IGS, psbK (5'-TTAGCCTTTGTTTGGCAAG-3') and psbI (5'-AGAGTTTGAGAGTAAGCAT-3') provided by Kim Ki-Joong for the IGS between $p s b \mathrm{~K}$ and $p s b \mathrm{I}$, 1FS (Lamb-Frye and Kron, 2003) and rbcL-1460R (5'-TTTAGTAAAAGATTGGGCCGAG-3') for $r b c L$. For PCR amplifications, predenaturation was first conducted at $94^{\circ} \mathrm{C}$ for $3 \mathrm{~min}$, followed by 30 cycles of (1) denaturation at $94^{\circ} \mathrm{C}$ for $30 \mathrm{~s}$, (2) annealing at $48^{\circ} \mathrm{C}-54^{\circ} \mathrm{C}$ for $30 \mathrm{~s}$, and (3) extension at $72^{\circ} \mathrm{C}$ for 1 $\min$. At the end of the cycles, a final extension was used at $72^{\circ} \mathrm{C}$ for $10 \mathrm{~min}$. PCR products were purified using the PEG precipitation procedure (Johnson and Soltis, 1995). Sequencing reactions were performed by Beijing Sanbo Biological Engineering Technology and Service Corporation, China. Sequences were aligned using CLUSTAL X software (Thompson et al., 1997), 
Table 1 Voucher information for the 19 species of Atraphaxideae

\begin{tabular}{|c|c|c|c|c|c|c|c|c|}
\hline \multirow[t]{2}{*}{ Genera } & \multirow[t]{2}{*}{ Section } & \multirow{2}{*}{$\begin{array}{l}\text { Species } \\
\text { A. bracteata A. Los. }\end{array}$} & \multirow{2}{*}{$\begin{array}{l}\text { Voucher } \\
\begin{array}{l}\text { M.L. Zhang } 0811 \\
\text { (XJBI) }\end{array}\end{array}$} & \multirow{2}{*}{$\begin{array}{l}\text { Source } \\
\text { TBG, Xinjiang, China }\end{array}$} & \multicolumn{4}{|c|}{ 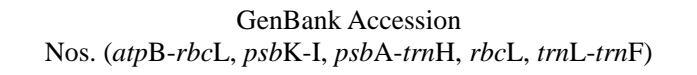 } \\
\hline & & & & & JQ009204 & JQ009242 & JQ009223 & JQ009261 JQ009279 \\
\hline \multirow{7}{*}{ Atraphaxis L. } & \multirow{4}{*}{ Tragpyrum } & A. jrtyschensis Yang et Han & $\begin{array}{l}\text { M.Z. Chen } 0821 \\
\text { (XJBI) }\end{array}$ & MBG, Gansu, China & JQ009208 & JQ009246 & JQ009227 & JQ009265 JQ009283 \\
\hline & & A. manshurica Kitag. & $\begin{array}{l}\text { M.Z. Chen } 0822 \\
\text { (XJBI) }\end{array}$ & $\begin{array}{l}\text { Lanzhou, Gansu, } \\
\text { China }\end{array}$ & JQ009211 & JQ009249 & JQ009230 & JQ009268 JQ009286 \\
\hline & & $\begin{array}{l}\text { A. virgata } \\
\text { (Regel) Krassn. }\end{array}$ & $\begin{array}{l}\text { B.R. Pan } 0881 \\
\text { (XJBI) }\end{array}$ & $\begin{array}{l}\text { Tuoli, Xinjiang, } \\
\text { China }\end{array}$ & JQ009209 & JQ009247 & JQ009228 & JQ009266 JQ009284 \\
\hline & & $\begin{array}{l}\text { A. pungens } \\
\text { (Bieb.) Jaub. et Spach }\end{array}$ & $\begin{array}{l}\text { M.L. Zhang } 0812 \\
\text { (XJBI) }\end{array}$ & TBG, Xinjiang, China & JQ009210 & JQ009248 & JQ009229 & JQ009267 JQ009285 \\
\hline & \multirow{3}{*}{ Atraphaxis } & A. spinosa L. & $\begin{array}{l}\text { M.Z. Chen } 0823 \\
\text { (XJBI) }\end{array}$ & MBG, Gansu, China & JQ009207 & JQ009245 & JQ009226 & JQ009264 JQ009282 \\
\hline & & A. compacta Ledeb. & $\begin{array}{l}\text { Y.X. Sun } 0806 \\
\text { (XJBI) }\end{array}$ & $\begin{array}{l}\text { Urumqi, Xinjiang, } \\
\text { China }\end{array}$ & JQ009206 & JQ009244 & JQ009225 & JQ009263 JQ009281 \\
\hline & & A. replicate Lam. & $\begin{array}{l}\text { B.R. Pan } 0871 \\
\text { (XJBI) }\end{array}$ & $\begin{array}{l}\text { Altai, Xinjiang, } \\
\text { China }\end{array}$ & JQ009205 & JQ009243 & JQ009224 & JQ009262 JQ009280 \\
\hline \multirow{9}{*}{ Calligonum L. } & $\begin{array}{l}\text { Calliphysa } \\
\text { (Fisch. et Mey.) Endl. }\end{array}$ & $\begin{array}{l}\text { C. junceum } \\
\text { (Fisch. et Mey. ) Litv. }\end{array}$ & M.L. Zhang 0844 & TBG, Xinjiang, China & JQ009214 & JQ009252 & JQ009233 & JQ009271 JQ009289 \\
\hline & \multirow{3}{*}{$\begin{array}{l}\text { Pterococcus } \\
\text { (Pall.) Endl. }\end{array}$} & $\begin{array}{l}\text { C. aphyllum } \\
\text { (Pall.) Gürke }\end{array}$ & M.L. Zhang 0841 & TBG, Xinjiang, China & JQ009215 & JQ009253 & JQ009234 & JQ009272 JQ009290 \\
\hline & & $\begin{array}{l}\text { C. leucocladum } \\
\text { (Schrenk) Bge. }\end{array}$ & M.L. Zhang 0845 & TBG, Xinjiang, China & JQ009218 & JQ009256 & JQ009237 & JQ009275 JQ009293 \\
\hline & & C. rubicundum Bge. & M.L. Zhang 0848 & TBG, Xinjiang, China & JQ009212 & JQ009250 & JQ009231 & JQ009269 JQ009287 \\
\hline & Calligonum & C. densum Borszcz. & M.L. Zhang 0843 & TBG, Xinjiang, China & JQ009216 & JQ009254 & JQ009235 & JQ009273 JQ009291 \\
\hline & \multirow{4}{*}{$\begin{array}{l}\text { Medusa Sosk. et } \\
\text { Alexandr. }\end{array}$} & C. arborescens Litv. & M.L. Zhang 0842 & TBG, Xinjiang, China & JQ009219 & JQ009257 & JQ009238 & JQ009276 JQ009294 \\
\hline & & C. mongolicum Turcz & M.L. Zhang 0846 & TBG, Xinjiang, China & JQ009220 & JQ009258 & JQ009239 & JQ009277 JQ009295 \\
\hline & & C. roborowskii A. Los. & M.L. Zhang 0847 & TBG, Xinjiang, China & JQ009213 & JQ009251 & JQ009232 & JQ009270 JQ009288 \\
\hline & & C. zaidamense A. Los. & M.L. Zhang 0849 & TBG, Xinjiang, China & JQ009217 & JQ009255 & JQ009236 & JQ009274 JQ009292 \\
\hline \multicolumn{2}{|l|}{ Parapteropyrum A. J. Li } & P. tibeticum A. J. Li & Z.Z. Zhou 0801 & Jiacha,Tibet, China & JQ009221 & JQ009259 & JQ009240 & JQ009278 JQ009296 \\
\hline \multicolumn{2}{|l|}{$\begin{array}{l}\text { Pteropyrum Jaub. } \\
\text { \& Spach. }\end{array}$} & P. aucherii Jaub. et Spach & $\begin{array}{l}\text { A.L. Ashirova, F. } \\
\text { Kerimova \& al. s.n. (LE) }\end{array}$ & $\begin{array}{l}\text { Kaakhnishsky, Turcoman } \\
\text { (LE) }\end{array}$ & JQ009222 & JQ009260 & JQ009241 & \\
\hline
\end{tabular}

Note: TBG, Turpan Botonical Garden; MBG, Minqin Botonical Garden; LE, Herbarium of Vascular Plants, Komarov Botanical Institute of Russian Academy of Sciences 
and then adjusted by hand. All gaps were treated as missing characters. Finally, the $r b c \mathrm{~L}$ dataset and five-gene dataset of $a t p \mathrm{~B}-r b c \mathrm{~L}, p s b \mathrm{~A}-t r n \mathrm{H}, t r n \mathrm{~L}-t r n \mathrm{~F}$, $p s b \mathrm{~K}-p s b \mathrm{I}$ and $r b c \mathrm{~L}$ were combined and used for phylogenetic analyses.

\subsection{Phylogenetic analyses}

Sequences of coding regions, such as $r b c \mathrm{~L}$, were conserved in sequence length, and alignments were straightforward. In contrast, sequences of noncoding regions showed length variation and it was necessary to introduce indels in the alignment. We did not include indel information in our phylogenetic analyses. The phylogenetic analyses (Maximum Parsimony, Maximum Likelihood and Bayesian Inference) of $r b c \mathrm{~L}$ and 5-gene datasets, respectively, were conducted using PAUP* 4.0b10 (Swofford, 2002) and MrBayes 3.1 (Huelsenbeck and Ronquist, 2001). Maximum parsimony searches were performed using heuristic search methods: tree-bisection-reconnection (TBR), branches collapsed (creating polytomies) if the maximum branch length was zero, and all characters weighed equally. The analyses were repeated 100 times with a random order of sequence addition in an attempt to sample multiple islands of the most parsimonious trees. Bootstrap analyses (Felsenstein, 1985) under MP analyses were performed to assess the relative support of the branches. Heuristic search settings identical to those above were used to estimate bootstrap values (BS) with 1,000 replicates. For searching the likelihood tree, the same MP parameters were used with PAUP*. For ML analyses, Modeltest 3.6 (Posada and Crandall, 1998) was used, and the nucleotide substitution model $\mathrm{GTR}+\mathrm{G}+\mathrm{I}$ was generated. Bayesian analyses were conducted using MrBayes, version 3.0b4 (Huelsenbeck and Ronquist, 2001; Huelsenbeck and Rannala, 2004).
Four chains were run (Markov Chain Monte Carlo), beginning with a random tree and saving a tree every 100 generations, for one million generations.

The incongruence length difference (ILD) test (Farris et al., 1994, 1995) for the combined data set of five genes was implemented in PAUP*.

\section{Results}

\subsection{Aligned DNA sequences}

The aligned sequence information for each gene marker is presented in Table 2. The five-gene data set was not significantly incongruent based on the ILD tests $(P=0.28)$.

\subsection{Phylogenetic analyses}

\subsection{1 $r b c \mathrm{~L}$ analysis}

Four genera of Atraphaxideae were placed in an analysis mostly containing genera of Polygonoideae to investigate their general position in Polygonoideae.

The four genera of Atraphaxideae were found in a large clade (Fig. 1), and within this clade, three subclades (A-C) were discovered. Clade A corresponded to Calligonum and Pteropyrum alone; clade B contained Parapteropyrum, Fagopyrum and the genera of the currently recognized tribe Rumiceae. Parapteropyrum and Fagopyrum were closely related (MP/PP=99/1.00). The third (clade C) included Atraphaxis, Polygonum s. str., Polygonella and Fallopia, and was also strongly supported (MP/PP=100/1.00). Atraphaxis was strongly supported (MP/PP $=82 / 1.00)$ as a sister to the clade including Polygonum s. str. and Polygoneae.

There were slight differences in the topologies re covered by MP, ML and Bayesian analyses. As sister to Calligonum, Pteropyrum received low support in

Table 2 Data set and tree statistics from separate maximum parsimony analyses of $r b c L$ and combined 5 gene

\begin{tabular}{|c|c|c|c|c|c|c|c|c|}
\hline Genic region & $\begin{array}{l}\text { Aligned seq. } \\
\text { length (bp) }\end{array}$ & $\begin{array}{l}\text { No. of variable } \\
\text { sites }\end{array}$ & No. of PIS ${ }^{a}$ & $\begin{array}{l}\text { No. of } \mathrm{MP}^{\mathrm{b}} \\
\text { trees }\end{array}$ & $\begin{array}{l}\text { Length of MP } \\
\text { trees }\end{array}$ & $\begin{array}{l}\text { Consistency } \\
\text { index (CI) }\end{array}$ & $\begin{array}{l}\mathrm{CI} \text { (excl. in- } \\
\text { variant sites) }\end{array}$ & $\begin{array}{l}\text { Retention } \\
\text { index (RI) }\end{array}$ \\
\hline$r b c \mathrm{~L}$ & 1,380 & 385 & 243 & 99 & 710 & 0.6252 & 0.5281 & 0.7997 \\
\hline 5-сpDNA & 4,439 & 630 & 235 & 9 & 745 & 0.9163 & 0.8108 & 0.9559 \\
\hline
\end{tabular}

Note: ${ }^{a}$ parsimony-informative sites; ${ }^{\mathrm{b}}$ most parsimonious 

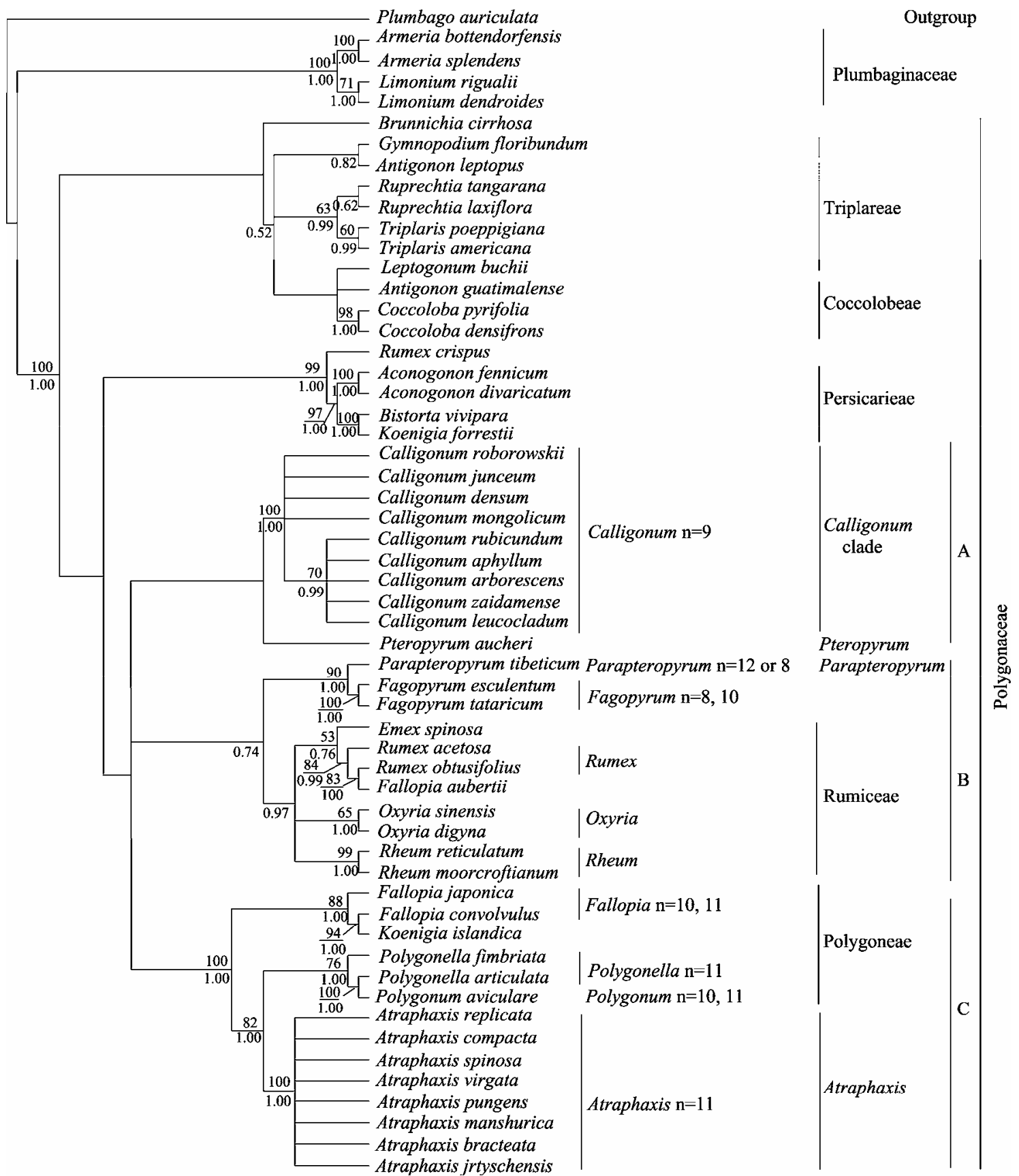

Fig. 1 Topology resulting from maximum likelihood analysis of $r b c \mathrm{~L}$ data set using Garli $(\mathrm{GTR}+\mathrm{G}+\mathrm{I})$. Bootstrap support values (> 50\%) are indicated above the branches; posterior probabilities $(>0.5)$ are presented below the branches.

MP and Bayesian analysis (Fig. 1).

\subsubsection{Five-gene analysis}

The monophyly of Atraphaxis and Calligonum were both well supported. Within Atraphaxis, a clade formed by A. spinosa, A. compacta and A. replicata was strongly supported (Fig. 2). In addition, $A$. spinosa was most closely related to A. compacta, with a poor MP but high Bayesian support (MP/PP=65/ 1.00). The relationships among the remaining species were less resolved except for a poorly supported (MP/PP=60/0.68) clade that included A. virgata, $A$. pungens and A. manshurica. Within Calligonum, there was a clade with strong Bayesian support ( $\mathrm{PP}=0.94)$, including C. aphyllum, C. arborescens, C. leucocla- 


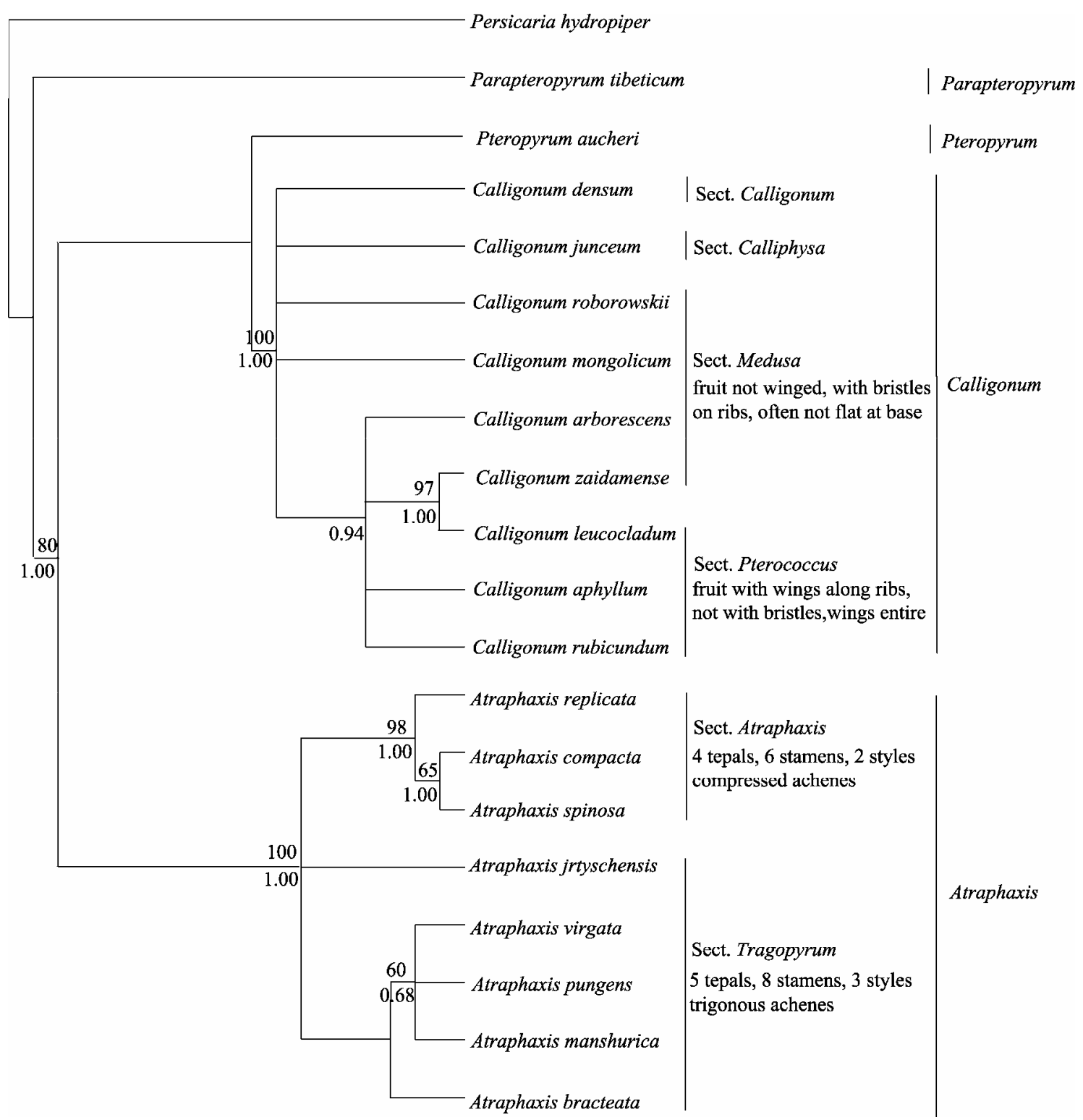

Fig. 2 Topology resulting from maximum likelihood analysis for the combined data set of 5-cpDNA genes (atpB-rbcL, $p s b \mathrm{~A}, p s b \mathrm{~K}-\mathrm{I}, r b c \mathrm{~L}$, and $t r n \mathrm{~L}-\mathrm{F}$ ) using Garli $(\mathrm{GTR}+\mathrm{G}+\mathrm{l})$. Bootstrap support values of maximum parsimony (MP) $>50 \%$ or posterior probability support Bayesian inference $(\mathrm{PP})>0.5$ are indicated above and below the branches, respectively.

dum, C. rubicundum, and C. zaidamense. And C. leucocladum and C. zaidamense form a sister pair $(\mathrm{MP} / \mathrm{PP}=97 / 1.00)$.

\section{Discussion and conclusion}

\subsection{Non-monophyly of Atraphaxideae}

Since the four genera in Atraphaxideae were placed in three separate clades in each of the analyses, Atraphaxideae in the phylogenetic tree of this study (Fig. 1) was clearly shown to be not monophyletic. This con- firms previous molecular phylogenies (Sanchez et al., 2009; Tavakkoli et al., 2010) and the inferences from chromosome karyotypes (Tian et al., 2009), but it is contradicted by traditional morphological taxonomy, as mentioned above.

Recent molecular phylogenies (Sanchez et al., 2009; Tavakkoli et al., 2010; Sanchez et al., 2011) have shown that the four genera of Atraphaxideae did not form a monophyletic group, and only Calligonum and Pteropyrum were closely united in a single clade. However, few Atraphaxis species were sampled in the 
previous studies. Sanchez et al. (2009) and Tavakkoli et al. (2010) each sampled only two species. This is obviously insufficient for this genus, which includes about twenty-five species. Furthermore, in an ITS tree (Sanchez et al., 2009; Fig. 2), two Atraphaxis species did not form a clade. This suggests that it is necessary to sample more taxa and more genes to obtain a robust molecular phylogeny. The present paper attempted to complement sufficient Atraphaxis samples with an increased sampling of their genes to detect relationships within Atraphaxis and among Atraphaxideae. Eight species were sampled from Atraphaxis collected in China, and five cpDNA sequences were conducted.

\subsubsection{Placement of Atraphaxis}

Atraphaxis is shown to be related to Polygonum s. str. and Polygonella (Fig. 1). This coincides with the classification systems of Haraldson (1978) and Brandbyge (1993). Both included Atraphaxis, Polygonum s. str. and Polygonella in the tribe Polygoneae. Our results agreed with previous molecular systematic studies (Lamb-Frye and Kron, 2003; Sanchez and Kron, 2008; Sanchez and Kron, 2009; Sanchez et al., 2009; Tavakkoli et al., 2010). Interestingly, Atraphaxis, sister to Polygonella and Polygonum s. str., had the same basic chromosome number, $\mathrm{n}=11$ (Polygonum $\mathrm{n}=11$ or 10) (Tian et al., 2009). Therefore, combined molecular, karyological and morphological data confirm that these three genera can be classified into one group.

\subsubsection{Placement of Parapteropyrum}

Parapteropyrum and Fagopyrum have a close relationship in the result tree (Fig. 1). This relationship was first noticed by Sanchez et al. (2009), and then by Tavakkoli et al. (2010). Parapteropyrum, a monotypic genus, is endemic to a narrow region of Tibet. Its diagnostic characters are an acute apex in the achene, calyx with entire wings in the fruit (wings have no break and do not divide into two), and inflorescences in the racemes. These characters are different from that of Pteropyrum, both genera at first was thought to be closely related in morphology. However, this morphological similarity could not obtain support from molecular evidence.

Fagopyrum is usually classified in Persicarieae (Ronse Decraene and Akeroyd, 1988; Brandbyge, 1993), and is distinguished from putatively related genera by the character of thick folded cotyledons lying in the center of the achene (Nakai, 1926; Ohnishi, 1998). This genus has been claimed to be closely related to Fallopia or Persicaria (Ronse Decraene and Akeroyd, 1988), but the morphological similarity between Fagopyrum and Fallopia or Persicaria was not confirmed by molecular evidence.

Although there are some differences between Parapteropyrum (shrub, unequal tepals) and Fagopyrum (herb, equal tepals), some similarities between them include: simple leaves, petiolate; ocrea membranous, oblique; bisexual flowers; perianth persistent, fiveparted; stamens eight; styles three; stigmas capitate; achenes trigonous; perianth persistent, five-parted; and exine microreticulate. These characters of general morphology and pollen coincided with the molecular phylogeny. In other words, both morphology and molecular phylogeny provided convincing evidence for a close relationship between Parapteropyrum and Fagopyrum. As a result, it is likely that Parapteropyrum should be interpreted as being a hexaploid based on $\mathrm{n}=8$, as found in Fagopyrum (Fig. 1), rather than a tetraploid based on $\mathrm{n}=12$, as suggested previously by Tian et al. (2009).

\subsubsection{Placement of Calligonum and Pteropyrum}

A relationship between Calligonum and Pteropyrum had been suggested based on morphology (Tavakkoli et al., 2008) and molecular evidence (Sanchez et al., 2009; Tavakkoli et al., 2010). The topologies of our $r b c \mathrm{~L}$ tree revealed a similar result, though not with high MP and Bayesian support (Fig. 1). Considering the weak relationship found between Pteropyrum and Calligonum, we prefer to suggest the similarities between Pteropyrum and Calligonum probably to be a convergence.

In the classification systems of Haraldson (1978) and Brandbyge (1993), the four Atraphaxideae genera plus Fagopyrum, Fallopia (Fallopia was absent in Polygoneae), Oxygonum, Polygonum s. str., Polygonella and Reynoutria were included in the tribe Polygoneae. This treatment for the tribe Polygoneae can not be supported by the present study, since the members of this tribe do not form a single clade and are scattered throughout subfamily Polygonoideae (Fig. 1). 


\subsection{Infrageneric relationships in Atrapahxis and Calligonum}

Since only one of four to five species of Pteropyrum was sampled and Parapteropyrum is monotypic, we pay attention to the infra-generic relationships of Atraphaxis and Calligonum respectively as follows. The monophyly of both genera respectively was well supported (Figs. 1, 2).

\subsubsection{Infrageneric relationships in Atraphaxis}

There are three sections recognized within Atraphaxis (Lovelius, 1978; Bao and $\mathrm{Li}$, 1993). The Chinese Ataphaxis species are divided into two sections (Bao and Li, 1993; Li et al., 2003), i.e., section Atraphaxis and section Tragopyrum. The species A. compacta, A. spinosa, $A$. canescens and $A$. replicata (variety of $A$. spinosa) were placed into section Atraphaxis, distinguished by four tepals, six stamens, two styles and lenticularly compressed achenes. The other species, characterized by five tepals, eight stamens, three styles and trigonous achenes, were members of section Tragopyrum. As shown in Fig. 2 (five-gene tree), our results, on the whole, coincide with this current sectional classification. The clade formed by A. compacta, A. spinosa and $A$. replicata, and belonging to section Atraphaxis, was strongly supported (MP/PP $=98 / 100)$ (note that $A$. replicata is sometimes treated as a variety of A. spinosa). A. jrtyschensis was not included a weak supported clade made up of four species, $A$. virgata, $A$. pungens, A. manshurica and $A$. bracteata in section Tragopyrum (Fig. 2). Section Atraphaxis and section Tragopyrum differ in morphological aspect, including tepal number, stamen number, style number and achene shape (Fig. 2), the present molecular phylogenetic tree is congruent with their dissimilarities.

\subsubsection{Infra-generic relationships in Calligonum}

According to Mao et al. (1983), Mabberley (1990), Bao and Li (1993), Li et al. (1998), Li et al. (2003) and Tavakkoli et al. (2008), Calligonum possesses $30-80$ species. It is a xeromorphic plant, and is distributed from northern Africa and southern Europe to Central Asia, including northwestern China as well as northeastern China. Three to four sections have been recognized in Calligonum: Calliphysa, Calligonum, Medusa and Pterococcus (Pavlov, 1936; Mao et al., 1983; Li et al., 2003) but Rechinger and Schi-
man-Czaika (1968) and Tavakkoli et al. (2008) did not recognize section Medusa.

Recently, Tavakkoli et al. (2008) presented a cladistic analysis of 18 species using 30 morphological characters. The results revealed that Calligonum was monophyletic and composed of two clades: one including the winged fruit species (section Pterococcus), and the other the bristled fruit taxa (section Calligonum). We sampled nine species that represented all four sections. The five-gene tree (Fig. 2) provided an identical topology for Calligonum, which was illustrated as absolutely monophyletic with high support $\mathrm{MP} / \mathrm{PP}=100 / 1.00$. However, none of the sections was monophyletic. A possible monophyletic clade was section Pterococcus with Bayesian support $\mathrm{PP}=94$ (in the five-gene tree), however, since $C$. arborescens and $C$. zaidamense of section Medusa are nested within section Pterococcus, this destroyed the monophyly of section Medusa. It is notable that $C$. zaidamense from section Medusa and C. leucocladum from section Pterococcus show a close relationship with high support MP/PP=97/1.00. Together with the results of the morphological cladistic study (Tavakkoli et al., 2008) in which C. arborescens of section Medusa is nested in section Calligonum, these results shown the necessity of carrying out a comprehensive study of Calligonum with much increased sampling.

\subsection{Incongruence among morphology, chromo- some and molecular phylogeny in Atraph- axideae evolution}

Concerning the evolution of the tribe, different opinions have been proposed in the light of the evidence, mainly from morphology, pollen, embryo and chromosome karyotype. In addition to the evolutionary trends for Atraphaxideae, Calligonum was proposed as the least derived genus. Based on a comprehensive evolutionary trend analysis of embryo, pollen and morphology, Bao and $\mathrm{Li}$ (1993) suggested that Atraphaxis is the most primitive in Atraphaxideae, and within Atraphaxis, section Tragopyrum is more primitive than section Atraphaxis. In Calligonum, in terms of chromosome numbers and anatomy of young branches, Mao et al. (1983) considered section Calliphysa, identifying $C$. junceum as the most primitive, and section Medusa as the most advanced, but there 
are many different opinions (Mao et al., 1983). Chromosome basic numbers have been treated as an important evolutionary feature in Polygonaceae, $n=11$ being considered the most likely primitive number and others being hypothesized to have derived from it (Jaretzky, 1928). Maekawa (1964) considered $n=14$ to be the original basic number in the family Polygonaceae, leading to a descending aneuploid series. Tian et al. (2009) also suggested that aneuploid evolution played an important role in the early diversification of the Atraphaxideae.

Even though we have broadly sampled the outgroup and sequenced five genes, we could not sufficiently discuss the Atraphaxideae evolution from molecular phylogeny since we were unable to determine which taxon was primitive or advanced in the phylogenetic trees. In other words, we could not find the evolutionary trend from molecular phylogeny, like a chromosome or one consistent with it. From the rbcL tree (Fig. 1), the scattered Atraphaxideae clades are paraphyletic, thus the most primitive taxon could not be ascertained. Similarly, within Atraphaxis, sections Atraphaxis and Tragopyrum were paraphyletic, so we could not judge which was primitive or advanced. Moreover, we found some contradictions between the general morphologi-

\section{References}

Bao B J, Li A J. 1993. A study of the genus Atraphaxis in China and the system of Atraphaxideae (Polygonaceae). Acta Phytotaxonomica Sinica, 31: 127-139.

Brandbyge J. 1993. Polygonaceae. In: Kubitzki K, Bittich V. The Families and Genera of Vascular Plants. Berlin: Springer, 531-544.

Dammer U. 1893. Polygonaceae. In: Engler H G A, Prantl K A E. Die natürlichen Pflanzenfamilie. Leipzig: Engelmann, 1-36.

Doyle J J, Doyle J L. 1987. A rapid DNA isolation procedure for small quantities of fresh leaf material. Phytochemical Bulletin, 19: 11-15.

Farris J S, Källersjö M, Kluge A G, et al. 1994. Testing significance of incongruence. Cladistics, 10: 315-319.

Farris J S, Källersjö M, Kluge A G, et al. 1995. Constructing a significance test for incongruence. Systmatic Biology, 44: 570-572.

Felsenstein J. 1985. Confidence limits on phylogenies: an approach using the bootstrap. Evolution, 39: 783-791.

Haraldson K. 1978. Anatomy and taxonomy in Polygonaceae subfam. Polygonoideae Meisn. emend. Jaretzky. Symbolae Botanicae Upsaliensis, 22: 1-95.

Heywood V H, Brummitt P K, Culham A, et al. 2007. Flowering Plant cal taxonomic inference and molecular phylogeny. For instance, Parapteropyrum, a tetraploid or hexaploid species with narrow distribution in the Tibetan Plateau, should obviously be considered advanced in view of insights from the general morphology and chromosome base number. However, in the phylogenetic tree (five-gene tree, Fig. 2), it is derived from an ancestor of many taxa and seems primitive. To discuss the evolution of Atraphaxideae, much molecular work is needed in the future.

\section{Acknowledgements}

The research was supported by Chinese Academy of Sciences Important Direction for Knowledge Innovation Project (KZCX2-EW-305), Xinjiang Institute of Ecology and Geography, Chinese Academy of Sciences. Thanks to YiMin ZHAO (Institute of Botany, Chinese Academy of Sciences) for his kind help in the molecular sequence, to ZhongZhe ZHOU (Anhui University, Hefei, China) and Vyacheslav V. BYALT (LE Herbarium, Komarov Botanical Institute, Russian Academy of Sciences, St. Petersburg, Russia) for offering the leaf materials, to the staff of the Turpan Botanical Garden (Xinjiang, China) and Minqin Botanical Garden (Gansu, China) for permitting our leaf collection for DNA sequencing. Many thanks to Stewart C. SANDERSON (Shrub Sciences Laboratory, U.S. Department of Agriculture, Utah, USA) for his useful comments and English revisions on the manuscript.

Families of the World. London: Kew Publishing.

Hong S-P. 1995. Pollen morphology of Parapteropyrum and some putatively related genera (Polygonaceae-Atraphaxideae). Grana, 34: 153-159.

Huelsenbeck J P, Rannala B. 2004. Frequentist properties of Bayesian posterior probabilities of phylogenetic trees under simple and complex substitution models. Systmatic Biology, 53: 904-913.

Huelsenbeck J P, Ronquist F. 2001. MrBayes: Bayesian inference of phylogenetic trees. Bioinformatics, 17: 754-755.

Janssens S, Geuten K, Yuan Y M, et al. 2006. Phylogenetics of Impatiens and Hydrocera (Balsaminaceae) using chloroplast atpB-rbcL spacer sequences. Systmatic Botany, 33: 171-180.

Jaretzky R. 1925. Contributions to the systematics of the Polygonaceae with consideration of the oxymethyl-anthraquinone-occurrence. Feddes Repertorium, 22: 49-83.

Jaretzky R. 1928. Histological and karyological studies on Polygonaceae. Jahrbuecher fur Wissenschaftliche Botanik, 69: 357-490.

Johnson L A, Soltis D E. 1995. Phylogenetic inference in Saxifragaceae sensu stricto and Gilia (Polemoniaceae) using matK sequences. An- 
nals of the Missouri Botanical Garden, 82: 149-175.

Lamb-Frye A S, Kron K A. 2003. Phylogeny and character evolution in Polygonaceae. Systmatic Botany, 28: 326-332.

Li A J, Bao B J, Grabovskava-Borodina A E, et al. 2003. Polygonaceae. In: Wu Z Y, Raven P H. Flora of China. Beijing: Science Press and St. Louis: Missouri Botanical Garden Press, 5: 277-350.

Li A J, Kao Z T, Mao Z M, et al. 1998. Polygonaceae. In: Wu Z Y, Chen X Q. Flora Reipublicae Popularis Sinicae, vol. 25. Beijing: Science Press, 120-142.

Lovelius O L. 1978. Synopsis generis Atraphaxis L. (Polygonaceae). Novosti Sistematiki Vysshikh Rastenii, 15: 85-108.

Mabberley D J. 1990. The Plant Book. Cambridge: Cambridge University Press.

Mao Z M, Yang G, Wang C G. 1983. Studies on chromosome numbers and anatomy of young branches of Calligonum of Xinjiang in relation to the evolution of some species of the genus. Acta Phytotaxonomica Sinica, 21: 44-49.

Maekawa F. 1964. On the phylogeny in the Polygonaceae. Journal of Japanese Botany, 39: 14-18.

Nakai T. 1926. A new classification of Linnean Polygonum. Rigakkai, 24: 289-301.

Ohnishi O. 1998. Search for the wild ancestor of buckwheat I. description of new Fagopyrum (Polygonaceae) species and their distribution in China and the Himalayan hills. Fagopyrum, 15: 18-28.

Pavlov H B. 1936. Flora of USSR, vol 5. Moscow: Science Press.

Posada D, Crandall K A. 1998. Modeltest: testing the model of DNA substitution. Bioinformatics, 14: 817-818.

Rechinger K H, Schiman-Czeika H. 1968. Polygonaceae. In: Rechinger. Flora Iranica. Graz: Akademische Druck-u Verlagsanstalt. 56.

Ronse Decraene L P, Akeroyd J R A. 1988. Generic limits in Polygonum and related genera (Polygonaceae) on the basis of floral characters. Botanical Journal of the Linnean Society, 98: 321-371.

Sanchez A, Kron K A. 2008. Phylogenetics of Polygonaceae with an emphasis on the evolution of Eriogonoideae. Systmatic Botany, 33: 87-96.
Sanchez A, Kron K A. 2009. Phylogenetic relationships of Afrobrunnichia Hutch. \& Dalziel (Polygonaceae) based on three chloroplast genes and ITS. Taxon, 58: 781-792.

Sanchez A, Schuster T M, Kron K A. 2009. A large-scale phylogeny of Polygonaceae based on molecular data. International Journal of Plant Sciences, 170: 1044-1055.

Sanchez A, Schuster T M, Burke J M, et al. 2011. Taxonomy of Polygonoideae (Polygonaceae): a new tribal classification. Taxon, 60: 151-160.

Sang T, Crawford J, Stuessy T F. 1997. Chloroplast DNA phylogeny, reticulate evolution, and biogeography of Paeonia (Paeoniaceae). American Journal of Botany, 84: 1120-1136.

Swofford D L. 2002. PAUP*: phylogenetic analysis using parsimony, v. 4.0b10. Sunderland: Sinauer Associates.

Taberlet P, Gielly L, Pautou G, et al. 1991. Universal primers for amplification of three non-coding regions of chloroplast DNA. Plant Molecular Biology, 17: 1105-1109.

Takhtajan A. 2009. Flowering Plants. Berlin: Springer.

Tate J A, Simpson B B. 2003. Paraphyly of Tarasa (Malvaceae) and diverse origins of the polyploid species. Systmatic Botany, 28: 723-737.

Tavakkoli S, Osaloo S K, Maassoumi A A. 2008. Morphological cladistic analysis of Calligonum and Pteropyrum (Polygonaceae) in Iran. Iran Journal of Botany, 14: 117-125.

Tavakkoli S, Kazempour Osaloo S, Maassoumi A A. 2010. The phylogeny of Calligonum and Pteropyrum (Polygonaceae) based on nuclear ribosomal DNA ITS and chloroplast trnL-F sequences. Iranian Journal of Biotechnology, 8: 1-15.

Thompson J D, Gibson T J, Plewniak F, et al. 1997. The clustal X windows interface: flexible strategies for multiple sequence alignment aided by quality analysis tools. Nucleic Acids Research, 24: 4876-4882.

Tian X M, Liu R R, Tian B, et al. 2009. Karyological studies of Parapteropyrum and Atraphaxis (Polygonaceae). Caryologia, 62: 261-266. 


\section{Appendix}

Sequence data downloaded from the Genbank rbcL-Aconogonon divaricatum L., FM883603; Aconogonon xfennicum Reiersen, FM883604; Antigonon guatimalense Meisn., FJ154449; Antigonon leptopus Hook. \& Arn., AF297146; Armeria bottendorfensis A. Schulz, Z97640; Armeria splendens (Lag. \& Rodr.) Webb, Y16908; Bistorta vivipara (L.) S.F. Gray, EU840288; Brunnichia cirrhosa Gaertn., AF297136;

Coccoloba densifrons Mart. ex Meisn., AF297138; Coccoloba pyrifolia Desf., Z97647;

Emex spinosai (L.) Gampdera, AF297142;

Fagopyrum esculentum Moench, EU840292; Fagopyrum tataricum (L.) Gaertn., D86287; Fallopia aubertii (L. Henry) Houlub, EU840324; Fallopia convolvulus (L.) Löve, FM883612; Fallopia japonica (Houtt.) Dcne., AF297131; Gymnopodium floribundum Rolfe, GQ206220; Koenigia forrestii (Diels) Mesicek \& Sojak., AF297144;

Koenigia islandica L., EF653763;

Leptogonum buchii Urb., GQ206223;

Limonium rigualii M.B., Z97645;
Limonium dendroides Svent., Z97644;

Oxyria digyna (L.) Hill., EU840291;

Oxyria sinensis Hemsl., AF297148;

Persicaria hydropiper f. ciliare Domin, FM883629;

Plumbago auriculata Lam., EU002283;

Polygonella articulate (L.) Meisn., EF653760;

Polygonella fimbriata (Elliot) Horton, AF297132;

Polygonum aviculare L., AF297127;

Pteropyrum aucheri Jaub. et Spach, GQ206227;

Rheum moorcroftianum Royle, EU840300;

Rheum reticulatum A. Los., EU840299;

Rumex acetosa L., AY395559;

Rumex crispus L., EU840290;

Rumex obtusifolius L., AF297126;

Ruprechtia laxiflora Meisn., EF437987;

Ruprechtia tangarana Standl., GQ206233;

Triplaris americana L., Y16910;

Triplaris poeppigiana Weddell., AF297137.

psbK-psbI-Persicaria hydropiper f. ciliare Domin, EU749803.

trnL-trnF-Persicaria hydropiper f. ciliare Domin, EF653806.

psbA-trnH-Persicaria hydropiper f. ciliare Domin, EF653754. 